\title{
Analisis Perilaku Belajar Dan Minat Belajar Terhadap Pemahaman Akuntansi Dengan Kecerdasan Intelektual Sebagai Variabel Intervening (Studi Pada Mahasiswa S1 Akuntansi Periode 2017 - 2018 UPN "Veteran" Jawa Timur)
}

\author{
Muhamad Fadel Ardiansyah, Endah Susilowati \\ Prodi Akuntansi Fakultas Ekonomi dan Bisnis \\ Universitas Pembangunan Nasional "Veteran" Jawa Timur \\ muhfadelardiansyah@gmail.com
}

\begin{abstract}
Higher education institutions are required to not only produce graduates who have mastered abilities in the academic field, but also have technical analytical skills in the field of humanistic skills and professional skills so that they have added value in competing in the world of work. The problem that arises in this research is the understanding of accounting that changes or fluctuates in the Accounting Students of UPN "Veteran" East Java during the period 2017 - 2018. The type of research used is the type of research using quantitative approaches. The results of this study indicate that learning behavior has a significant effect on understanding accounting, learning interest has a significant effect on accounting understanding, learning behavior has a significant effect on intellectual intelligence, learning interest has a significant effect on intellectual intelligence, intellectual intelligence has a significant effect on accounting understanding, learning behavior has no effect. on understanding of accounting through intellectual intelligence, and interest in learning has a significant effect on understanding of accounting through intellectual intelligence.
\end{abstract}

Keyword : Intellectual Intelligence, Learning Behaviour, And Understanding of Accounting.

\section{Pendahuluan}

Pendidikan merupakan faktor yang paling penting bagi kehidupan yang harus didapatkan dan dilaksanakan oleh seluruh masyarakat termasuk mahasiswa. Suatu lembaga pendidikan dituntut untuk dapat menggali dan mengembangkan potensi yang dimiliki oleh mahasiswanya dalam rangka mendukung mahasiswa mendapatkan pendidikan yang baik. Melalui sistem pendidikan yang baik mahasiswa diharapkan mampu meningkatkan prestasi akademiknya sehingga dapat menjadi mahasiswa yang berkualitas.

Akuntansi merupakan suatu sistem dengan input data/informasi dan output berupa informasi dan laporan keuangan yang bermanfaat bagi pengguna internal dan eksternal entitas (Martani et al., 2016), dalam dunia pendidikan terutama pendidikan tinggi akuntansi, banyak hal yang harus diperhatikan untuk menciptakan mahasiswa yang berkualitas yang dapat memahami pelajaran yang diberikan oleh dosen pengajar, terutama dalam hal sistem pengajaran yang disampaikan oleh pengajar dan bobot pelajaran yang disampaikan, dari apa yang disampaikan oleh pengajar, kecerdasan yang dimiliki oleh siswa sangat mempengaruhi bagaimana suatu materi yang disajikan dapat dipahami dan diminati, terutama kecerdasan intelektual.

Pendidikan akuntansi yang diselenggarakan di UPN "Veterean" Jawa Timur melalui Program Studi Akuntansi dapat menjadi wadah mahasiswa dalam meningkatkan kualitas dirinya. Program Studi Akuntansi mendidik mahasiswanya untuk menjadi seorang akuntan profesional yang memiliki pemahaman dibidang akuntansi serta mampu mengaplikasikan ilmunya di dunia kerja.

Pendidikan tinggi akuntansi yang menghasilkan lulusan dalam bidang akuntansi saat 
ini dituntut untuk tidak hanya menghasilkan lulusan yang menguasai kemampuan di bidang akademik, tetapi juga mempunyai kemampuan yang bersifat teknis analisis dalam bidang humanistic skill (kemampuan menghadirkan diri secara manusiawi dalam kehidupan masyarakat yang turut bertanggungjawab bagi kelangsungan nilai-nilai kemanusiaan dan kemasyarakatan) dan professional skill (kemampuan melaksanakan profesinya dengan berbekalkan pengetahuan akademik yang memadai dalam rangka mengaktualisasikan dirinya di masyarakat) sehingga mempunyai nilai tambah dalam bersaing di dunia kerja (Suryanti Budhiyanto J. \& Nugroho \& Ika P, 2004).

Perilaku belajar pada mahasiswa saat di perguruan tinggi mempengaruhi tingkat pemahaman akuntansi, dosen menetapkan sumber pengetahuan apa saja yang perlu dipelajari oleh mahasiswa dalam bentuk silabus atau program belajar, kemudian mahasiswa menjalani program belajar yang telah disediakan, dan dosen yang mengontrol proses belajar mahasiswa, untuk itu tingkat pemahaman akuntansi akan dilihat dari perilaku belajar laku. Minat belajar berkaitan dengan penggunaan waktu yang baik untuk belajar. Minat belajar yang tinggi akan dapat terwujud apabila mahasiswa sadar akan tanggungjawab mereka sebagai mahasiswa, sehingga mampu meningkatkan motivasi dan disiplin diri agar mampu mencapai target yang diinginkan dalam memahami suatu materi yang berhubungan dengan akuntansi (Rokhana, L. A., \& Sutrisno, 2016), jika seseorang yang mempunyai minatbelajar yang kuat akan diperkirakan pemahaman akuntansinya juga sangat baik. Penelitian yang dilakukan oleh (Rokhana, L. A., \& Sutrisno, 2016) menemukan bahwa minat belajar berpengaruh terhadap tingkat pemahaman akuntansi.

(Goleman, 1999) berpendapat bahwa keberhasailan kita dalam kehidupan ditentukan oleh kecerdasan intelektual dan kecerdasan emosional, tidak hanya oleh IQ, tetapi kecerdasan intelektual yang memegang peranan. IQ menyumbang kira-kira 20 persen bagi faktor-faktor yang menentukan sukses dalam hidup, maka yang mana 80 persen diisi oleh kekuatankekuatan lain.

Mahasiswa Akuntansi UPN "Veteran" Jawa Timur yang sedang menempuh jurusan Akuntansi diharapkan nantinya dapat menerapkan pemahaman akuntansinya didunia kerja, dan tingkat pemahaman akuntansi pada seorang mahasiswa dinyatakan mengerti terhadap apa yang sudah dipelajari dalam konteks ini mengacu pada mata kuliah akuntansi yang telah ditempuh dan Indeks Prestasi Kumulatif (IPK) yang telah dicapai sebagai bukti kecerdasan intelektual mempengaruhinya. Pada tahun 2020 mahasiswa periode 2017 dan 2018 yang telah menempuh mata kuliah jurusan akuntansi diantaranya ada yang dapat memahami akuntansi karena minat belajar dan perilaku belajar yang telah dilakukan dengan baik, dan diantaranya dapat memahami akuntansi dengan kecerdasan intelektual yang dia miliki sejak lahir. Lebih jelasnya peneliti telah menyebarkan kuesioner pra penelitian secara acak terhadap mahasiswa Program Studi Akuntansi Fakultas Ekonomi dan Bisnis UPN "Veteran" Jawa Timur periode 2017 dan 2018 mengenai pemahaman akuntansi.

Masalah yang timbul dalam penelitian ini adalah pemahaman akuntansi yang mengalami perubahan atau berfluktuasi pada Mahasiswa Akuntansi UPN "Veteran" Jawa Timur selama periode tahun 2017 - 2018. Hasil dari kuesioner pra penelitian menyatakan bahwa dari 50 mahasiswa, 84\% atau 42 mahasiswa setuju menganggap minat belajar membantu dalam pemahaman akuntansi sedangkan $16 \%$ atau 8 mahasiswa tidak setuju akan pernyataan tersebut. 54\% atau 27 mahasiswa setuju bahwa perilaku belajar mampu mendorong pemahaman akuntansi sedangkan $46 \%$ atau 23 mahasiswa tidak setuju dengan pernyataan tersebut. $70 \%$ atau 35 mahasiswa tidak setuju bahwa kecerdasan intelektual mampu dalam mendorong pemahaman akuntansi pada seseorang sedangkan $30 \%$ atau 15 mahasiswa setuju dengan pernyataan tersebut. Sebanyak $64 \%$ atau 32 mahasiswa memiliki keyakinan dalam pemahaman akuntansi, sedangkan $36 \%$ atau 18 mahasiswa tidak memiliki dalam hal tersebut.

Hasil pra penelitian sejalan dengan penelitian (Rokhana, L. A., \& Sutrisno, 2016) Perilaku belajar berpengaruh positif signifikan terhadap tingkat pemahaman akuntansi, hal ini 
mengindikasikan bahwa perilaku belajar yang baik akan membuat seorang mahasiswa lebih memahami materi kuliah, sehingga bisa menghasilkan prestasi akademik yang lebih baik dan Minat belajar berpengaruh positif signifikan terhadap tingkat pemahaman akuntansi, hal ini mengindikasikan bahwa minat belajar merupakan variabel yang penting yang berpengaruh terhadap tercapainya sebuah prestasi atau cita - cita yang diharapkan, belajar dengan minat akan jauh lebih baik hasilnya, bila di bandingkan dengan belajar tanpa disertai dengan adanya minat. Hal tersebut bertentangan dengan penelitian (Gayatri \& Wirawati, 2018) Perilaku belajar tidak berpengaruh positif terhadap pemahaman akuntansi. Variabel Kecerdasan Intelektual, Kecerdasan Emosional, Kecerdasan Spiritual Dan Perilaku Belajar Berpengaruh Positif Dan Signifikan Secara Statistik Pada Pemahaman Akuntansi.

Penelitian ini dilakukan untuk mengetahui Pengaruh Perilaku Belajar dan Minat Belajar terhadap Pemahaman Akuntansi pada Mahasiswa Program Studi Akuntansi di UPN "Veterean" Jawa Timur untuk mengetahui tingkat kecerdasan intelektual pada pemahaman akuntansi. Penelitian ini dianggap perlu dilakukan karena dengan mengetahui pengaruh perilaku belajar dan minat belajar mahasiswa tentang pemahaman akuntansi bagaimana nantinya mempengaruhi langsung terhadap pada lulusan Mahasiswa Program Studi Akuntansi di UPN "Veteran" Jawa Timur untuk siap di dunia kerja.

\section{Kajian Teori}

\subsection{Teori Perilaku Terencana}

Teori Perilaku Terencana atau TPB (Theory of Planned Behavior) merupakan pengembangan lebih lanjut dari Teori Perilaku Beralasan (Theory of Reasoned Action). TPB merupakan kerangka berpikir konseptual yang bertujuan untuk menjelaskan determinan perilaku tertentu. Menurut (Ajzen, 1991), faktor sentral dari perilaku individu adalah bahwa perilaku itu dipengaruhi oleh niat individu (behavior intention) terhadap perilaku tertentu tersebut. Niat untuk berperilaku dipengaruhi oleh tiga komponen yaitu (1) sikap (attitude), (2) norma subjektif (subjective norm) dan (3) persepsi kontrol keperilakuan (perceived behavior control).

Dalam TPB, sikap, norma subjektif, dan persepsi kontrol keperilakuan ditentukan melalui keyakinan-keyakinan utama. Determinan suatu perilaku merupakan hasil dari penilaian keyakinan- keyakinan dari individu, baik sebagai secara positif maupun negatif. Teori Perilaku Terencana atau TPB (Theory of Planned Behavior) didasarkan pada asumsi bahwa manusia adalah makhluk yang rasional dan menggunakan informasi-informasi yang mungkin baginya secara sistematis (Achmat, 2010). Orang memikirkan implikasi daritindakan mereka sebelum mereka memutuskan untuk melakukan atau tidak melakukan perilakuperilaku tertentu.

\subsection{Perilaku Belajar}

Perilaku adalah suatu tindakan yang dimiliki oleh setiap orang untuk melakukan hal yang ingin dicapai. Dalam proses belajar membutuhkan perilaku belajar yang sesuai dengan tujuan pendidikan yang efisien dan efektif sehingga prestasi akademik dapat ditingkatkan. Belajar yang efisien dapat dicapai bila mahasiswa menggunakan strategi yang tepat seperti penganturan waktu belajar dalam belajar di kampus maupun di rumah. Selain memiliki perilaku belajar yang baik seorang mahasiswa juga harus memiliki sikap disiplin, tanggungjawab dan motivasi yang kuat, perilaku belajar yang baik dan teratur akan mengasah kemampuan berfikir dan meningkatkan penguasaan materi yang dipelajari (Asih, 2020).

Perilaku belajar merupakan dimensi belajar yang dilakukan individu secara berulangulang yang menjadikan suatu "kebiasaan" individu tersebut. Perilaku belajar tidak dirasakan sebagai beban melainkan sebagai kebutuhan. Hal tersebut terjadi karena terus menerus dilakukan dengan bimbingan dan pengawasan serta keteladanan dalam semua aspek dan krestifitas pendidikan. Perilaku belajar seorang individu dapat menentukan prestasi yang akan dicapai oleh individu tersebut (Sari \& Sartika, 2018). 


\subsection{Minat Belajar}

Minat belajar adalah suatu usaha seseorang untuk tertarik dan menyukai sesuatu yang muncul dari dalam sehingga orang itu sering perhatian dalam aktivitas tersebut. Menurut Slameto dalam (Hermawan \& Rochmawati, 2019) menyatakan jika mahasiswa menyukai suatu pelajaran dan ia berminat dalam mempelajari pelajaran tersebut, maka mahasiswa tersebut akan lebih mengerti memahami dan akan memperoleh hasil yang memuaskan setelah ia mempelajari dengan minat yang tinggi.

(Slameto, 2001) menyatakan bahwa "Minat adalah suatu rasa dan suatu ketertarikan pada sesuatu hal atau aktivitas, tanpa ada yang menyuruh dan timbul tidak secara tiba-tiba atau spontan, melainkan timbul akibat partisipasi, pengetahuan dan kebiasaan. Minat juga diartikan sebagai kondisi yang terjadi disertai perasaan senang dihubungkan dengan kebutuhan atau keinginannya sendiri".

\subsection{Kecerdasan Intelektual}

Kecerdasan adalah suatu konsepsi lama tentang kekuatan (power) yang dapat melengkapi akal pikiran manusia dengan gagasan abstrak yang universal, untuk dijadikan sumber tunggal pengetahuan terjadi. Iteligensi memiliki tiga komponen yaitu kemampuan untuk mengarahkan pikiran dan tindakan, kemampuan mengubah arah tindakan jika tindakan telah dilaksanakan, kemampuan untuk mengubah diri sendiri.

Menurut (Gardner, 1993) yang menetang pendapat lama tentang pengertian IQ merumuskan bahwa kecerdasan adalah kemampuan menyelesaikan masalah atau menciptakan produk mode yang merupakan konsekuensi dalam suasana budaya atau masyarakat tertentu.

\subsection{Pemahaman Akuntansi}

Menurut Kamus Besar Bahasa Indonesia (KBBI, 2016), kata paham sebagai asal kata dari pemahaman yang artinya mengerti benar atau tahu benar. Sedangkan pemahaman merupakan suatu proses, cara, dan perbuatan memahami atau memahamkan. Kemampuan untuk memahami pada umumnya berkaitan dengan kemampuan untuk melihat hubungan antar masalah dan menjelaskan masalah tersebut secara benar serta dapat memahami makna hubungan tersebut guna memecahkan suatu masalah. Sedangkan pemahaman menunjukkan tentang bagaimana seseorang menggunakan suatu informasi yang telah mereka pelajari dan mereka ingat (Liviawati \& Aquino, 2013) dalam (Rohmah, 2019).

\section{Metode Penelitian}

Jenis penelitian yang digunakan adalah jenis penelitian dengan menggunakan pendeketan kuantitatif. Objek penelitian ini dilakukan terhadap Mahasiswa Program Studi Akuntansi Universitas Pembangunan Nasional "Veteran" Jawa Timur angkatan 2017 dan 2018. Populasi dalam penelitian ini adalah Mahasiswa Program Studi Akuntansi Universitas Pembangunan Nasional "Veteran" Jawa Timur angkatan 2017 dan angkatan 2018 yang memenuhi kriteria yaitu telah menempuh mata kuliah Pengantar Akuntasi 1, Pengantar Akuntasi 2, Akuntansi Keuangan Menengah 1, Akuntansi Keuangan Menengah 2, Akuntansi Keuangan Lanjutan 1, Auditing 1, Auditing 2, Akuntansi Biaya, Sistem Akuntansi. Penentuan sampel pada penelitian ini dengan metode simple random sampling yaitu dengan pengambilan sampel dari populasi dilakukan secara acak. Teknik pengumpulan data dengan menggunakan kuisioner yang terdiri dari serangkaian pertanyaan tertulis yang diajukan kepada responden, dokumentasi yang berasal dari bagian akademik program studi akuntansi UPN "Veteran" Jawa Timur dan kepustakaan dengan mengumpulkan buku maupun studi literatur. Teknik analisis data yang digunakan yaitu analisis deskriptif yang mengukur dua atau lebih variabel yang kedudukan kedua variabel tersebut sama atau tidak ada yang mempengaruhi atau dipengaruhi, analisis inferensial untuk menentukan sejauh mana kesamaan antara hasil yang diperoleh dari suatu sampel dengan hasil yang akan didapat pada populasi secara keseluruhan, analisa outer model dilakukan untuk memastikan bahwa variabel yang digunakan layak untuk dijadikan pengukuran (valid dan reliabel), analisa inner model dilakukan untuk memastikan bahwa 
model struktural yang dibangun kuat dan akurat dan uji hipotesis yang dilakukan dengan melihat nilai probabilitas. Nilai probabilitas atau nilai p-value dengan alpha 5\%.

\section{Hasil Dan Pembahasan}

\subsection{Hasil Penelitian}

\subsubsection{Jawaban Responden Pada Variabel Perilaku Belajar (X1)}

Perilaku adalah suatu tindakan yang dimiliki oleh setiap orang untuk melakukan hal yang ingin dicapai. Variabel perilaku belajar memiliki 12 (dua belas) item pertanyaan. Adapun hasil jawaban responden atas variabel perilaku belajar dapat dilihat pada tabel dibawah ini:

Tabel 1. Jawaban Responden Pada Variabel Perilaku Belajar (X1)

\begin{tabular}{|c|c|c|c|c|c|c|c|c|c|c|c|c|}
\hline \multirow{3}{*}{$\begin{array}{c}\text { Item } \\
\text { pernyataan }\end{array}$} & \multicolumn{10}{|c|}{ Skor } & \multirow{2}{*}{\multicolumn{2}{|c|}{ Total }} \\
\hline & \multicolumn{2}{|c|}{1} & \multicolumn{2}{|c|}{2} & \multicolumn{2}{|c|}{3} & \multicolumn{2}{|c|}{4} & \multicolumn{2}{|c|}{5} & & \\
\hline & $\mathrm{f}$ & $\%$ & $\mathrm{f}$ & $\%$ & $\mathrm{f}$ & $\%$ & $\mathrm{f}$ & $\%$ & $\mathrm{f}$ & $\%$ & $\mathrm{f}$ & $\%$ \\
\hline $\mathrm{X} 1.1$ & 0 & 0 & 8 & 9.3 & 22 & 26 & 30 & 35 & 26 & 30 & 86 & 100 \\
\hline $\mathrm{X} 1.2$ & 2 & 2.3 & 18 & 21 & 38 & 44 & 22 & 26 & 6 & 7 & 86 & 100 \\
\hline $\mathrm{X} 1.3$ & 4 & 4.7 & 23 & 27 & 38 & 44 & 9 & 11 & 12 & 14 & 86 & 100 \\
\hline X1.4 & 1 & 1.2 & 8 & 9.3 & 37 & 43 & 34 & 40 & 6 & 7 & 86 & 100 \\
\hline $\mathrm{X} 1.5$ & 0 & 0 & 16 & 19 & 38 & 44 & 24 & 28 & 8 & 9.3 & 86 & 100 \\
\hline X1.6 & 1 & 1.2 & 17 & 20 & 43 & 50 & 19 & 22 & 6 & 7 & 86 & 100 \\
\hline $\mathrm{X} 1.7$ & 0 & 0 & 14 & 16 & 43 & 50 & 23 & 27 & 6 & 7 & 86 & 100 \\
\hline X1.8 & 4 & 4.7 & 33 & 38 & 39 & 45 & 6 & 7 & 4 & 4.7 & 86 & 100 \\
\hline X1.9 & 9 & 11 & 41 & 48 & 32 & 37 & 0 & 0 & 4 & 4.7 & 86 & 100 \\
\hline $\mathrm{X} 1.10$ & 0 & 0 & 12 & 14 & 49 & 57 & 21 & 24 & 4 & 4.7 & 86 & 100 \\
\hline $\mathrm{X} 1.11$ & 0 & 0 & 27 & 31 & 32 & 37 & 23 & 27 & 4 & 4.7 & 86 & 100 \\
\hline $\mathrm{X} 1.12$ & 0 & 0 & 21 & 24 & 42 & 49 & 14 & 16 & 9 & 11 & 86 & 100 \\
\hline Mean & & 2.1 & & 23 & & 44 & & 22 & & 9.4 & & 100 \\
\hline
\end{tabular}

Berdasarkan hasil tanggapan responden pada tabel diatas dapat diperoleh kesimpulan bahwa sebagian besar responden memiliki perilaku belajar yang cukup baik, hal ini dapat dilihat dari rata-rata tertinggi jawaban responden yang berada pada skor 3 (cukup) sebesar $44 \%$.

\subsubsection{Jawaban Responden Pada Variabel Minat Belajar (X2)}

Minat belajar adalah suatu usaha seseorang untuk tertarik dan menyukai sesuatu yang muncul dari dalam sehingga orang itu sering perhatian dalam aktivitas tersebut. Variabel minat belajar memiliki 8 (delapan) item pertanyaan. Adapun hasil jawaban responden atas variabel minat belajar dapat dilihat pada tabel dibawah ini:

Tabel 2. Jawaban Responden Pada Variabel Minat Belajar (X2)

\begin{tabular}{|c|c|c|c|c|c|c|c|c|c|c|c|c|}
\hline \multirow{3}{*}{$\begin{array}{c}\text { Item } \\
\text { pernyataan }\end{array}$} & \multicolumn{10}{|c|}{ Skor } & \multirow{2}{*}{\multicolumn{2}{|c|}{ Total }} \\
\hline & \multicolumn{2}{|c|}{1} & \multicolumn{2}{|c|}{2} & \multicolumn{2}{|c|}{3} & \multicolumn{2}{|c|}{4} & \multicolumn{2}{|c|}{5} & & \\
\hline & $\mathrm{f}$ & $\%$ & $\mathrm{f}$ & $\%$ & $f$ & $\%$ & $f$ & $\%$ & $\mathrm{f}$ & $\%$ & f & $\%$ \\
\hline X2.1 & 0 & 0 & 18 & 21 & 39 & 45 & 19 & 22 & 10 & 12 & 86 & 100 \\
\hline $\mathrm{X} 2.2$ & 1 & 1.2 & 23 & 27 & 38 & 44 & 17 & 20 & 7 & 8.1 & 86 & 100 \\
\hline $\mathrm{X} 2.3$ & 0 & 0 & 11 & 13 & 45 & 52 & 23 & 27 & 7 & 8.1 & 86 & 100 \\
\hline $\mathrm{X} 2.4$ & 0 & 0 & 9 & 11 & 33 & 38 & 22 & 26 & 22 & 26 & 86 & 100 \\
\hline $\mathrm{X} 2.5$ & 0 & 0 & 9 & 11 & 15 & 17 & 31 & 36 & 31 & 36 & 86 & 100 \\
\hline $\mathrm{X} 2.6$ & 0 & 0 & 15 & 17 & 45 & 52 & 17 & 20 & 9 & 11 & 86 & 100 \\
\hline $\mathrm{X} 2.7$ & 0 & 0 & 1 & 1.2 & 24 & 28 & 34 & 40 & 27 & 31 & 86 & 100 \\
\hline X2.8 & 1 & 1.2 & 0 & 0 & 50 & 58 & 23 & 27 & 12 & 14 & 86 & 100 \\
\hline Mean & & 0.3 & & 13 & & 42 & & 27 & & 18 & & 100 \\
\hline
\end{tabular}


Berdasarkan hasil tanggapan responden pada tabel diatas dapat diperoleh kesimpulan bahwa sebagian besar responden memiliki minat belajar yang cukup baik, hal ini dapat dilihat dari rata-rata tertinggi jawaban responden yang berada pada skor 3 (cukup) sebesar $42 \%$.

\subsubsection{Jawaban Responden Pada Variabel Kecerdasan Intelektual (Y)}

Kecerdasan intelektual adalah kesanggupan untuk menyesuaikan diri kepada kebutuhan baru, dengan menggunakan alat-alat berfikir yang sesuai dengan tujuan. Variabel kecerdasan intelektual memiliki 10 (sepuluh) item pertanyaan. Adapun hasil jawaban responden atas variabel kecerdasan intelektual dapat dilihat pada tabel dibawah ini:

Tabel 3. Jawaban Responden Pada Variabel Kecerdasan Intelektual (Y)

\begin{tabular}{|c|c|c|c|c|c|c|c|c|c|c|c|c|}
\hline \multirow{3}{*}{$\begin{array}{c}\text { Item } \\
\text { pernyataan }\end{array}$} & \multicolumn{10}{|c|}{ Skor } & \multirow{2}{*}{\multicolumn{2}{|c|}{ Total }} \\
\hline & \multicolumn{2}{|c|}{1} & \multicolumn{2}{|c|}{2} & \multicolumn{2}{|c|}{3} & \multicolumn{2}{|c|}{4} & \multicolumn{2}{|c|}{5} & & \\
\hline & f & $\%$ & f & $\%$ & f & $\%$ & f & $\%$ & f & $\%$ & f & $\%$ \\
\hline Y1 & 0 & 0 & 0 & 0 & 15 & 17 & 37 & 43 & 34 & 40 & 86 & 100 \\
\hline Y2 & 0 & 0 & 0 & 0 & 14 & 16 & 40 & 47 & 32 & 37 & 86 & 100 \\
\hline Y3 & 0 & 0 & 0 & 0 & 17 & 20 & 42 & 49 & 27 & 31 & 86 & 100 \\
\hline Y4 & 1 & 1.2 & 0 & 0 & 38 & 44 & 35 & 41 & 12 & 14 & 86 & 100 \\
\hline Y5 & 0 & 0 & 1 & 1.2 & 28 & 33 & 37 & 43 & 20 & 23 & 86 & 100 \\
\hline Y6 & 0 & 0 & 1 & 1.2 & 13 & 15 & 34 & 40 & 38 & 44 & 86 & 100 \\
\hline Y7 & 0 & 0 & 0 & 0 & 11 & 13 & 26 & 30 & 49 & 57 & 86 & 100 \\
\hline Y8 & 0 & 0 & 1 & 1.2 & 19 & 22 & 33 & 38 & 33 & 38 & 86 & 100 \\
\hline Y9 & 0 & 0 & 2 & 2.3 & 28 & 33 & 33 & 38 & 23 & 27 & 86 & 100 \\
\hline Y10 & 0 & 0 & 1 & 1.2 & 29 & 34 & 35 & 41 & 21 & 24 & 86 & 100 \\
\hline Mean & & 0.1 & & 0.7 & & 25 & & 41 & & 34 & & 100 \\
\hline
\end{tabular}

Berdasarkan hasil tanggapan responden pada tabel diatas dapat diperoleh kesimpulan bahwa sebagian besar responden memiliki kecerdasan intelektual yang baik, hal ini dapat dilihat dari rata-rata tertinggi jawaban responden yang berada pada skor 4 (setuju) sebesar $41 \%$.

\subsubsection{Jawaban Responden Pada Variabel Pemahaman Akuntansi (Z)}

Mahasiswa dapat dikatakan memahami atau menguasai akuntansi apabila telah mampu mengaplikasikan atau menerapkan ilmu akuntansi yang telah didapatnya kedalam kehidupan bermasyarakat serta dalam dunia kerja. Variabel pemahaman akuntansi memiliki 9 (sembilan) item pertanyaan. Adapun hasil jawaban responden atas variabel pemahaman akuntansi dapat dilihat pada tabel dibawah ini:

Tabel 4. Jawaban Responden Pada Variabel Pemahaman Akuntansi (Z)

\begin{tabular}{|c|c|c|c|c|c|c|c|c|c|c|c|c|}
\hline \multirow{3}{*}{$\begin{array}{c}\text { Item } \\
\text { pernyataan }\end{array}$} & \multicolumn{10}{|c|}{ Skor } & \multirow{2}{*}{\multicolumn{2}{|c|}{ Total }} \\
\hline & \multicolumn{2}{|c|}{1} & \multicolumn{2}{|c|}{2} & \multicolumn{2}{|c|}{3} & \multicolumn{2}{|c|}{4} & \multicolumn{2}{|c|}{5} & & \\
\hline & f & $\%$ & f & $\%$ & f & $\%$ & f & $\%$ & $\mathbf{f}$ & $\%$ & $\mathbf{f}$ & $\%$ \\
\hline $\mathrm{Z} 1$ & 0 & 0 & 0 & 0 & 33 & 38 & 36 & 42 & 17 & 20 & 86 & 100 \\
\hline Z2 & 0 & 0 & 0 & 0 & 29 & 34 & 37 & 43 & 20 & 23 & 86 & 100 \\
\hline $\mathrm{Z3}$ & 0 & 0 & 0 & 0 & 18 & 21 & 51 & 59 & 17 & 20 & 86 & 100 \\
\hline $\mathrm{Z4}$ & 0 & 0 & 0 & 0 & 20 & 23 & 41 & 48 & 25 & 29 & 86 & 100 \\
\hline $\mathrm{Z5}$ & 0 & 0 & 0 & 0 & 4 & 4.7 & 39 & 45 & 43 & 50 & 86 & 100 \\
\hline Z6 & 0 & 0 & 0 & 0 & 5 & 5.8 & 40 & 47 & 41 & 48 & 86 & 100 \\
\hline $\mathrm{Z7}$ & 0 & 0 & 2 & 2.3 & 33 & 38 & 33 & 38 & 18 & 21 & 86 & 100 \\
\hline Z8 & 0 & 0 & 0 & 0 & 39 & 45 & 28 & 33 & 19 & 22 & 86 & 100 \\
\hline Z9 & 0 & 0 & 1 & 1.2 & 3 & 3.5 & 33 & 38 & 49 & 57 & 86 & 100 \\
\hline Mean & & 0 & & 0.4 & & 24 & & 44 & & 32 & & 100 \\
\hline
\end{tabular}

Berdasarkan hasil tanggapan responden pada tabel diatas dapat diperoleh kesimpulan bahwa sebagian besar responden memiliki pemahaman akuntansi yang baik, hal 
ini dapat dilihat dari rata-rata tertinggi jawaban responden yang berada pada skor 4 (setuju) sebesar $44 \%$.

\subsubsection{Uji Validitas}

Tabel 5. Nilai AVE

\begin{tabular}{|c|c|}
\hline Variabel & AVE \\
\hline $\mathrm{X} 1$ & 0.602 \\
\hline $\mathrm{X} 2$ & 0.582 \\
\hline $\mathrm{Y}$ & 0.575 \\
\hline $\mathrm{Z}$ & 0.601 \\
\hline
\end{tabular}

Nilai AVE dari semua variabel penelitian melebihi nilai 0,50. Artinya dapat disimpulkan bahwa perilaku belajar (X1), inat belajar (X2), kecerdasan intelektual (Y) dan pemahaman akuntansi $(\mathrm{Z})$ memiliki nilai validitas konvergen yang baik.

\subsubsection{Uji Reliabilitas}

Tabel 6. Composite Reliability dan Cronbach Alpha

\begin{tabular}{|c|c|c|}
\hline Variabel & Cronbach's Alpha & Composite Reliability \\
\hline X1 & 0.939 & 0.947 \\
\hline X2 & 0.896 & 0.917 \\
\hline Y & 0.917 & 0.931 \\
\hline Z & 0.917 & 0.931 \\
\hline
\end{tabular}

Tabel diatas menunjukkan bahwa nilai composite reliability dan Cronbach's Alpha dari semua variabel penelitian memiliki nilai lebih dari 0,70 sehingga dapat disimpulkan bahwa semua variabel penelitian memiliki reliabilitas yang tinggi.

\subsubsection{Evaluasi Model Struktural}

Tabel 7. Uji Hipotesis

\begin{tabular}{|l|l|c|c|}
\hline No. & & Path coefficients & P-Value \\
\hline 1. & $\mathrm{X} 1->\mathrm{Y}$ & 2.965 & 0.004 \\
\hline 2. & $\mathrm{X} 1->\mathrm{Z}$ & 2.303 & 0.024 \\
\hline 3. & $\mathrm{X} 2->\mathrm{Y}$ & 4.064 & 0.000 \\
\hline 4. & $\mathrm{X} 2->\mathrm{Z}$ & 2.376 & 0.020 \\
\hline 5. & $\mathrm{Y}>\mathrm{Z}$ & 2.320 & 0.023 \\
\hline
\end{tabular}

Adapun penjelasan dari tabel di atas adalah:

1. Perilaku belajar (X1) berpengaruh positif signifikan terhadap pemahaman akuntansi (Z) dilihat dari nilai koefisiennya sebesar 2,303 dengan tingkat signifikan (p-value) kurang dari 5\%. Sehingga hipotesis ke-1 yang menyatakan bahwa "Perilaku belajar berpengaruh signifikan terhadap pemahan akuntansi" teruji kebenarannya.

2. Minat belajar (X2) berpengaruh positif signifikan terhadap pemahaman akuntansi (Z) dilihat dari nilai koefisiennya sebesar 2,376 dengan tingkat signifikan (p-value) kurang dari $5 \%$. Sehingga hipotesis ke-2 yang menyatakan bahwa "Minat belajar berpengaruh signifikan terhadap pemahaman akuntansi" teruji kebenarannya.

3. Perilaku belajar (X1) berpengaruh positif signifikan terhadap kecerdasan intelektual (Y) dilihat dari nilai koefisiennya sebesar 2,965 dengan tingkat signifikan (p-value) kurang dari $5 \%$. Sehingga hipotesis ke-3 yang menyatakan bahwa "Perilaku belajar berpengaruh signifikan terhadap kecerdasan intelektual" teruji kebenarannya.

4. Minat belajar (X2) berpengaruh positif signifikan terhadap kecerdasan intelektual (Y) dilihat dari nilai koefisiennya sebesar 4,064 dengan tingkat signifikan (p-value) kurang dari 5\%. Sehingga hipotesis ke-4 yang menyatakan bahwa "Minat belajar berpengaruh signifikan terhadap kecerdasan intelektual" teruji kebenarannya.

5. Kecerdasan intelektual (Y) berpengaruh positif signifikan terhadap pemahaman akuntansi (Z) dilihat dari nilai koefisiennya sebesar 2,320 dengan tingkat signifikan (p-value) kurang 
dari 5\%. Sehingga hipotesis ke-5 yang menyatakan bahwa "Kecerdasan intelektual berpengaruh signifikan terhadap pemahaman akuntansi." teruji kebenarannya.

Tabel 8. Nilai R-Square

\begin{tabular}{|c|c|}
\hline & R Square \\
\hline $\mathrm{Y}$ & 0.474 \\
\hline $\mathrm{Z}$ & 0.551 \\
\hline
\end{tabular}

Berdasarkan tabel nilai $R$-square menunjukkan bahwa besarnya pengaruh perilaku belajar dan minat belajar terhadap kecerdasan intelektual sebesar 47,4\% dan besarnya pengaruh perilaku belajar, minat belajar dan kecerdasan intelektual terhadap pemahaman akuntansi sebesar 55,1\%.

Tabel 9. Pengaruh Tidak Langsung

\begin{tabular}{|l|c|c|}
\hline & T Statistics $(\mid$ O/STDEV|) & P Values \\
\hline X1 ->Z & 1.744 & 0.085 \\
\hline X2 -> Z & 2.066 & 0.042 \\
\hline
\end{tabular}

Berdasarkan table di atas dapat dijelaskan bahwa:

1. Variabel perilaku belajar (X1) tidak berpengaruh terhadap pemahaman akuntansi $(\mathrm{Z})$ melalui kecerdasan intelektual (Y) dilihat dari nilai uji t sebesar 1,744 dan p-value > 5\% yang berarti kecerdasan intelektual $(\mathrm{Y})$ tidak terbukti sebagai variabel mediasi antara perilaku belajar (X1) dengan pemahaman akuntansi (Z), sehingga hipotesis ke-6 yang menyatakan bahwa "Perilaku belajar berpengaruh signifikan terhadap pemahaman akuntansi melalui kecerdasan intelektual" tidak teruji kebenarannya.

2. Variabel minat belajar (X2) berpengaruh terhadap pemahaman akunatnsi (Z) melalui kecerdasan intelektual (Y) dilihat dari nilai uji t sebesar 2,066 dan dinyatakan signifikan (p-value < 5\%), yang berarti kecerdasan intelektual (Y) terbukti sebagai variabel mediasi antara minat belajar (X2) dengan pemahaman akuntansi (Z), sehingga hipotesis ke-7 yang menyatakan bahwa "Minat belajar berpengaruh signifikan terhadap pemahaman akuntansi melalui kecerdasan intelektual" teruji kebenarannya.

\subsection{Pembahasan}

\subsubsection{Pengaruh Perilaku Belajar Terhadap Tingkat Pemahaman Akuntansi}

Dalam penelitian terdahulu, (Mutia, 2015) hasil penelitian menunjukkan bahwa perilaku belajar berpengaruh signifikan positif terhadap tingkat pemahaman akuntansi. Penelitian (Mutia, 2015) juga diperkuat dengan penelitian yang dilakukan oleh (Rokhana, L. A., \& Sutrisno, 2016) dan (Mispiyanti \& Kristanti, 2017) yang menunjukkan hasil bahwa perilaku bejalar berpengaruh positif dan signifikan terhadap tingkat pemahaman akuntansi.

Hasil penelitian ini sependapat dengan pernyataan di atas bahwa perilaku belajar (X1) berpengaruh positif signifikan terhadap pemahaman akuntansi $(\mathrm{Z})$ dilihat dari nilai koefisiennya sebesar 2,303 dengan tingkat signifikan (p-value) kurang dari 5\%. Sehingga hipotesis ke-1 yang menyatakan bahwa "Perilaku belajar berpengaruh signifikan terhadap pemahan akuntansi" teruji kebenarannya.

\subsubsection{Pengaruh Minat Belajar Terhadap Tingkat Pemahaman Akuntansi}

Penelitian terdahulu menurut (Wulandari, 2018) menyatakan bahwa minat belajar berpengaruh positif signifikan terhadap pemahaman akuntansi, hal tersebut didukung dengan penelitian yang dilakukan oleh (Napitupulu, 2015).

Hasil penelitian ini sependapat dengan pernyataan di atas bahwa minat belajar (X2) berpengaruh positif signifikan terhadap pemahaman akuntansi $(\mathrm{Z})$ dilihat dari nilai koefisiennya sebesar 2,376 dengan tingkat signifikan (p-value) kurang dari 5\%. Sehingga hipotesis ke-2 yang menyatakan bahwa "Minat belajar berpengaruh signifikan terhadap pemahaman akuntansi" teruji kebenarannya. 


\subsubsection{Pengaruh Perilaku Belajar Terhadap Kecerdasan Intelektual}

Menurut (Riswandi \& Lakoni, 2017) diduga kecerdasan emosional, kecerdasan spritual, kecerdasan intelektual dan perilaku belajar berpengaruh terhadap tingkat pemahaman mata kuliah akuntansi.

Hasil penelitian ini sependapat dengan pernyataan di atas bahwa perilaku belajar (X1) berpengaruh positif signifikan terhadap kecerdasan intelektual (Y) dilihat dari nilai koefisiennya sebesar 2,965 dengan tingkat signifikan (p-value) kurang dari 5\%. Sehingga hipotesis ke-3 yang menyatakan bahwa "Perilaku belajar berpengaruh signifikan terhadap kecerdasan intelektual" teruji kebenarannya.

\subsubsection{Pengaruh Minat Belajar Terhadap Kecerdasan Intelektual}

Menurut (Sawaludin et al., 2017) menyimpulkan bahwa minat belajar berpengaruh signifikan dengan kecerdasan intelektual semakin tinggi motivasi semakin tinggi juga minat belajar untuk mempengaruhi kecerdasan intelektual.

Hasil penelitian ini sependapat dengan pernyataan di atas bahwa minat belajar (X2) berpengaruh positif signifikan terhadap kecerdasan intelektual (Y) dilihat dari nilai koefisiennya sebesar 4,064 dengan tingkat signifikan (p-value) kurang dari 5\%. Sehingga hipotesis ke-4 yang menyatakan bahwa "Minat belajar berpengaruh signifikan terhadap kecerdasan intelektual" teruji kebenarannya.

\subsubsection{Pengaruh Kecerdasan Intelektual Terhadap Tingkat Pemahaman Akuntansi}

Kecerdasan intelektual merupakan hal yang penting dalam memahami akuntansi. Mahasiswa yang mengambil jurusan akuntansi harus memiliki kecerdasan intelektual yang baik maka akan memiliki pemahaman akuntansi yang baik pula. Dalam penelitian terdahulu menurut (Wulandari, 2018) menyatakan bahwa kecerdasan intelektual berpengaruh positif signifikan terhadap pemahaman akuntansi.

Hasil penelitian ini sependapat dengan pernyataan di atas bahwa kecerdasan intelektual (Y) berpengaruh positif signifikan terhadap pemahaman akuntansi (Z) dilihat dari nilai koefisiennya sebesar 2,320 dengan tingkat signifikan (p-value) kurang dari 5\%. Sehingga hipotesis ke-5 yang menyatakan bahwa "Kecerdasan intelektual berpengaruh signifikan terhadap pemahaman akuntansi." teruji kebenarannya.

\subsubsection{Pengaruh Perilaku Belajar Terhadap Pemahaman Akuntansi Melalui Kecerdasan Intelektual}

Perilaku belajar yang efektif dan efisien akan menimbulkan sikap disiplin dan bertanggungjawab dalam proses belajar. Dalam penelitian terdahulu, (Mutia, 2015) hasil penelitian menunjukkan bahwa perilaku belajar berpengaruh signifikan positif terhadap tingkat pemahaman akuntansi. Penelitian (Mutia, 2015) juga diperkuat dengan penelitian yang dilakukan oleh (Rokhana, L. A., \& Sutrisno, 2016) dan (Mispiyanti \& Kristanti, 2017) yang menunjukkan hasil bahwa perilaku bejalar berpengaruh positif dan signifikan terhadap tingkat pemahaman akuntansi.

Hasil penelitian ini sependapat dengan pernyataan di atas bahwa perilaku belajar (X1) tidak berpengaruh terhadap pemahaman akuntansi $(\mathrm{Z})$ melalui kecerdasan intelektual (Y) dilihat dari nilai uji t sebesar 1,744 dan p-value > 5\% yang berarti kecerdasan intelektual (Y) tidak terbukti sebagai variabel mediasi antara perilaku belajar (X1) dengan pemahaman akuntansi (Z), sehingga hipotesis ke-6 yang menyatakan bahwa "Perilaku belajar berpengaruh signifikan terhadap pemahaman akuntansi melalui kecerdasan intelektual" tidak teruji kebenarannya.

\subsubsection{Pengaruh Minat Belajar Terhadap Pemahaman Akuntansi Melalui Kecerdasan Intelektual}

Menurut (Wulandari, 2018) secara simultan Kecerdasan Intelektual (KIN), Kecerdasan Emosional (KEM), Kecerdasan Spiritual (KSP) dan Minat Belajar (MB) berpengaruh positif signifikan terhadap pemahaman akuntansi. 
Hasil penelitian ini sependapat dengan pernyataan di atas bahwa minat belajar (X2) berpengaruh terhadap pemahaman akunatnsi (Z) melalui kecerdasan intelektual (Y) dilihat dari nilai uji t sebesar 2,066 dan dinyatakan signifikan ( $\mathrm{p}$-value $<5 \%$ ), yang berarti kecerdasan intelektual (Y) terbukti sebagai variabel mediasi antara minat belajar (X2) dengan pemahaman akuntansi (Z), sehingga hipotesis ke-7 yang menyatakan bahwa "Minat belajar berpengaruh signifikan terhadap pemahaman akuntansi melalui kecerdasan intelektual" teruji kebenarannya.

\section{Kesimpulan dan Saran \\ 5.1 Kesimpulan}

Berdasarkan hasil penelitian yang diolah menggunakan metode Partial Least Square, diperoleh kesimpulan yaitu Perilaku belajar berpengaruh signifikan terhadap pemahan akuntansi, minat belajar berpengaruh signifikan terhadap pemahaman akuntansi, Perilaku belajar berpengaruh signifikan terhadap kecerdasan intelektual, Minat belajar berpengaruh signifikan terhadap kecerdasan intelektual, Kecerdasan intelektual berpengaruh signifikan terhadap pemahaman akuntansi, Perilaku belajar tidak berpengaruh terhadap pemahaman akuntansi melalui kecerdasan intelektual, dan Minat belajar berpengaruh signifikan terhadap pemahaman akuntansi melalui kecerdasan intelektual.

\subsection{Saran}

Berdasarkan uraian diatas, maka dapat ditemukan saran yang dapat dijadikan bahan pertimbangan dalam melakukan peneliatian selanjutnya yaitu diharapkan dapat menambahkan atau menggunakan variabel lain sebagai variabel yang telah ada yang dapat berpengaruh terhadap Tinhgkat Pemahaman Akuntansi mahasiswa.

\section{Referensi}

Achmat, Z. (2010). Theory of Planned Behavior, Masihkah Relevan? Diambil Dari: Http://Zakarija. Staff. Umm. Ac. Id/Files/20.

Ajzen, I. (1991). The theory of planned behavior. Organizational Behavior and Human Decision Processes. https://doi.org/10.1016/0749-5978(91)90020-T

Asih, S. P. T. (2020). Intelektual , Fasilitas Pembelajaran Dan Hasil Belajar Terhadap Pemahaman Akuntansi ( Studi Kasus Mahasiswa Akuntansi Fakultas Ekonomi Dan Bisnis UPS Tegal ). Intelektual, Fasilitas Pembelajaran Dan Hasil Belajar Terhadap Pemahaman Akuntansi ( Studi Kasus Mahasiswa Akuntansi Fakultas Ekonomi Dan Bisnis UPS Tegal ).

Gardner, H. (1993). Inteligencias múltiples. La teoría en la práctica. In paidos.

Gayatri, N. P. L., \& Wirawati, N. G. P. (2018). Pengaruh Kecerdasan Intelektual, Kecerdasan Emosional, Kecerdasan Spiritual Dan Perilaku Belajar Terhadap Tingkat Pemahaman Akuntansi. ISOQUANT: Jurnal Ekonomi, Manajemen Dan Akuntansi, 1(1), 79. https://doi.org/10.24269/iso.v1il.47

Goleman, D. (1999). Emotional Intelligence Kecerdasan Emosional Mengapa EI lebih penting dari pada IQ. PT. Gramedia Pustaka Utama.

Hermawan, R., \& Rochmawati. (2019). Pengaruh Kecerdasan Emosional, Minat Belajar, dan Hasil Belajar Pengantar Akuntansi Terhadap Tingkat Pemahaman Akuntansi Mahasiswa S1 Prodi Pendidikan Akuntansi Fakultas Ekonomi Universitas Negeri Surabaya. Pendidikan Akuntansi, 53(9), 1689-1699. 
KBBI. (2016). Kamus Besar Bahasa Indonesia ( KBBI ). In Kementerian Pendidikan dan Budaya.

Martani, D., Siregar, S. V., Wardhani, R., Farahmita, A., \& Tanujaya, E. (2016). Akuntansi Keuangan Menengah Berbasis PSAK. In Salemba Empat.

Rohmah, N. (2019). PENGARUH KECERDASAN EMOSIONAL, PERILAKU BELAJAR, DAN KOMPETENSI DOSEN TERHADAP PEMAHAMAN AKUNTANSI (Studi pada Mahasiswa Akuntansi Syariah Fakultas Ekonomi dan Bisnis Islam IAIN Surakarta). 4(1), $75-84$.

Rokhana, L. A., \& Sutrisno, S. (2016). No Title. Pengaruh Kecerdasan Emosional, Perilaku Belajar, Dan Minat Belajar Terhadap Tingkat Pemahaman Akuntansi.(Studi Empiris Pada Mahasiswa Akuntansi Fakultas Ekonomika Dan Bisnis UNTAG Semarang), 31(1)(Media Ekonomi dan Manajemen).

S., B. B., Spearman, C., \& Jones, L. W. (1950). Human Ability: A Continuation of the Abilities of Man. Journal of the Royal Statistical Society. Series A (General). https://doi.org/10.2307/2980883

Sari, I. P., \& Sartika, R. (2018). Pengaruh Perilaku Belajar, Gaya Mengajar Dosen, Dan Kecerdasan Emosional Terhadap Pemahaman Mahasiswa Pada Mata Kuliah Pengantar Akuntansi. Menara Ekonomi, Iv(2), 39-49.

Slameto. (2001). Evaluasi Pendidikan. Bumi Aksara.

Suryanti Budhiyanto J. \& Nugroho \& Ika P. (2004). Pengaruh Kecerdasan Emosional terhadap Tingkat Pemahaman Akuntansi. Jurnal Ekonomi Bisnis, X, No.2, H. 